\title{
GOVERNMENT POLICY FOR THE DEVELOPMENT OF FDI IN INDIAN RETAIL SECTOR: AN OVERVIEW
}

\section{Shambhu Kumar Gupta}

\author{
Research Scholar L. N. Mithila University, Darbhanga
}

ABSTRACT

Foreign direct investment (FDI) in multi-brand retailing in India is a red-hot topic, yet the kerfuffle over it is hardly new. As a concomitant of globalization of the world economy since 1990s the barriers to international trade are fast disappearing and in consequence there is in an increasing and uninterrupted flow of goods and services across the world. This paper is a modest attempt to study the Govt. policy for the development of FDI in Indian Retail Sector.

\section{KEYWORDS : Foreign Direct Investment, Indian Retail Sector, Multi Brand Retailing}

\section{INTRODUCTION}

Today, as much as two-thirds of the world trade, amounting to a whopping $\$ 2$ trillion, is accounted for by some 1000-odd multinationals enterprises (MNEs) (Roy, 2012). The Chinese frontier having been already won, there is no surprise that the MNEs will be vying for the lucrative retails market in an emerging economy like India where about 10 percent of the country's total GDP of USD 1 trillion comes from retails sales to Indian consumers (KPMG, 2010; Mukherjee and Patel, 2005). The size of the Indion retail market is, indeed, too big to be ignored. But at the same time, the inherent risk in allowing the MNEs entrée into the Indian retail market is far bigger and is not affordable without further thought about all its attendant hazards.

Retailing is the interface between the producer and the individual consumer, which ends up with buying for personal consumption. Without doubting its antiquity, it can be said that it is one of the oldest enterprises and commercial endeavours that civilization has known. The importance of retail can be appreciated from the following scenario of retail business in India:

- Retail sector in India is estimated to account for about $10 \%$ share in GDP, as compared to $8 \%$ in China, 6\% in Brazil and $10 \%$ in USA.

- India may be called the nation of the shopkeepers because, with 15 million outlets, it has the highest density of retail outlets in the world.

- Indian retails sector is highly fragmented in nature, only $4 \%$ of Indian retail outlets are larger than 500 sq. feet.

- Organised retail is just $5 \%$ of the total retail market, whereas $95 \%$ of the total retail trade in India is in unorganised sector.

- Unorganised Retail industry in India is the second largest employer after agriculture, employing about $8 \%$ of total work force (Around 40 million person).

Indian economy was hunted by various socio-economic problems in the immediate aftermath of independence. Such socio-economic problems are: poor industrial production, raising population, food security, unemployment, division of country, rehabilitation problem, etc. To overcome these problems, there was an immediate need to make India stable and growth oriented. In underdeveloped economy resource are scarce, development work cannot be started in all the back-word sectors. First of all identified the leading sector and scarce resources are to be mobilized to the leading sector. Thus, an economy started development for a long period.

Importance of FDI in Retail Trade in India

Modernization of retail business is more relevant for growth factor for rural area as well as economy of the country. We know that there is story linkage between the farm sector and the national economy of the country. It is fact that reforms in retail trade will push up the rural economy and also economy of the country as a whole. It would have multi-dimensional achievements to farmers, customers, small and medium business units and Government also. FDI in retail will benefit of the country widely as it will bring investments into development of fill back-end infrastructure such as, coldchain and supply chain that will further enhance efficiencies in the food chain, reduce very high levels of wastage and help to control food prices. The modern retailers can, and do, prosper step by step, raising employment opportunities along with supply chain, increasing earnings of farmers, reducing damage of products and transporting the products to the customers without middlemen. Moreover, FDI in retail business would bring green and eco-friendly technology in farming. It would enable the case for genetically modified food. FDI in retail business will allow investment opportunities in agricultural sector. This would favour suppliers linked to the FDI houses. It will benefit the domestic farming for economies point of view. As the global corporate players find it advantages to import at low price from other part of the world, they will do that. This is no doubt a bright side of FDI in retail.

In recent times, FDI in retail business is the most relevant issue as we have been worried about economy of the country slowing growth phase, serious fall in the market, exit of foreign investment and gradual decline of the rupee value. Moreover, FDI in retail sector will integrate farmers and medium and small enterprises into the modern trading system. It also ensuring they received moderate price of their products. FDI in retail is healthy for farmers as well as customers because, it provides efficiency and choice. Rational of FDI in retail sector in India is due to

- FDI in single and multi-brand retail will pave the way for improving supply chain infrastructure and logistics.

- It will curb inflation.

- It will result in reduced cost to the ultimate consumer and enable a fair return to the farmers.

- Economy will get the benefit with capital inflows from global giants that will develop the front-end and back-end infrastructure in different segments.

- It would act as an important employment absorber for the present social system.

- The consumer will get access to some of the major global brands. Entry of foreign brands would also improve the quality and variety of products, increase competition and expand manufacturing.

According to the $8^{\text {th }}$ Annual Global Retail Development Index (GRDI) of A T Kearney, India retail industry is the most promising emerging market for investment.

India has potentialities in retail sector as it has

- High consumer spending over the years by the young 
population

- Rising disposable income;

- Rise in the purchasing power of Indians;

- Improvements in infrastructure;

- Liberalization of the Indian economy;

- Increase in urbanization:

- Rise of self-employed class;

- Shift in consumer demand to foreign brands;

- The Internet revolution making the Indian consumer more accessible to the growing influence of domestic and foreign retail chains;

- Strategic location and geography;

- Vast growing economy.

\section{FDI Policy in Indian Retail Sector}

'FDI' means investment by non-resident entity/person resident outside India in the capital of an Indian company under Schedule 1 of Foreign Exchange Management (Transfer or Issue of Security by a Person Resident Outside India) Regulations, 2000. In India, the Ministry of Commerce and Industry acts as a nodal agency for monitoring and reviewing FDI policy on a continuous basis. The FDI policy is notified through Press Notes released from time to time by Secretariat for Industrial Assistance (SIA), Department of Industrial Policy and Promotion (DIPP). The foreign investors are free to invest, except in few sectors, where prior approval from RBI or FIPB would be required.

\section{FDI policy related to Single product Retail Trading}

FDI in Single Brand product retail trading is allowed $100 \%$ viz. automatic up to $49 \%$ and Government route beyond $49 \%$. The circular shows that Foreign Investment in Single Brand retail trading aimed at attracting investments in production and marketing, improving the availability of such goods for the consumer, encouraging increased sourcing of goods from India, and enhancing competitiveness of Indian enterprises through access to global designs, technologies and management practices, as per DIPP consolidated FDI policy circular of 2015. FDI in single brand product retail trading is subject to certain conditions such as:

- Products to be sold should be of single brand only.

- Products sold should be of same brand internationally.

- Single Brand' covers only products which are branded during manufacturing.

- In case of proposals involving FDI beyond $51 \%$, sourcing of $30 \%$ of the value of goods purchased will be done from India, preferably MSME's village and cottage industries, artisans and craftsmen, in all sectors.

- Applications would be processed firstly by DIPP and then by the FIPB for Government approval.

FDI policy related to Multi Brand Retail Trading

FDI in Multi Brand Retail Trading is allowed upto $51 \%$ through Government route, as per DIPP policy.

FDI in Multi brand retail trading is subject to certain conditions such as:

- Fresh agriculture produce (fruits, vegetables, flowers, grains, pulses, fresh poultry, fishery and meat products) may be unbranded.

- The foreign investor must bring a minimum amount of US $\$$ 100 million for investment.

- At least $50 \%$ of the investment bought should be invested in 'back-end infrastructure' within three years. Expenditure on land cost and rentals will not be included in infrastructure development.

- At least $30 \%$ of the products purchased must be sourced from Indian micro, small and medium industries (total investment in plant and machinery not exceeding US $\$ 2.0$ million)

- Government possess the first right of procurement on agriculture produce.

- Retail outlets are allowed to be set up in cities with a population of more than 10 lakh as per 2011 census survey, or any other cities as per the decisions of the respective State Governments.

- The policy for FDI is an enabling policy, the State Governments are set free for implementation of the policy.

- Applications are to be processed firstly by DIPP followed by the FIPB for Government approval.

Retail trading in any form by means of e-commerce is not permissible for FDI, engaged in multi brand or single brand retail trading.

\section{CONCLUSION:}

The Ministry of Commerce and Industry, Government of India is the nodal agency for motoring and reviewing the FDI policy on continued basis and changes in sectoral policy/sectoral equity cap. The FDI policy is notified through Press Notes by the Secretariat for Industrial Assistance (SIA), Department of Industrial Policy and (DIPP). The foreign investors are free to invest in India, except few sectors Promotion /activities, where prior approval from the RBI or Foreign Investment Promotion Board (FIPB) would be required. 100\% FDI being permitted in cash \& carry wholesale trading under the government approval route, subsequently brought under the automatic route in 2006. As a step ahead, FDI in single brand retail was permitted to the extent of $51 \%$ in 2006, while FDI in multi-brand retail remained prohibited till recently. Despite changes in consumer behaviour and retail modernization, India is one of the few countries where FDI was prohibited in multi-brand retail (until 2011), primarily to protect the traditional momand-pop retailers. This policy restricts global low-cost multibrand retailers such as Wal-Mart, Tesco and Metro AG from catering directly to Indian consumers. Within the country, there has been significant debate on whether FDI should be allowed in multi-brand retail. In July 2010, the Department of Industrial Policy and Promotion (DIPP) released a Discussion Paper on 'Foreign Direct Investment (FDI) in Multi-Brand Retail Trading' to facilitate discussion and debate on whether FDI should be allowed in multi-brand retail and, if so, what conditions should be imposed on FDI. Although a number of issues have been discussed in the Discussion Paper, the implications of the liberalization for Indian consumers have not been discussed. The Economy Survey of 2010-11 mentioned that a phased opening of FDI in multi-brand retail is likely to benefit the consumers, but did not state the exact benefits. In July 2011, a Committee of Secretaries (CoS) had cleared the proposal to allow up to $51 \%$ FDI in multi-brand retail, which has been approved by the Union Cabinet in November 2011, albeit with a few riders to set up the supply chain and reduce inflation. The Union Cabinet has also approved increasing the FDI limit in single brand retail to $100 \%$ with government approval. while no parliamentary approval is needed for the decision, State Governments have the prerogative to disallow the same in their respective states.

\section{REFERENCES:}

1. Roy, Sujit Kumar (2012), Millennium Development Goals and Growth of Critical Social Infrastructures in India, Research Bulletin, The Institute of Cost Accountants of India, Vol. XXXV, pp. 91-99

2. www.kpmg.com

3. Mukherjee, Arpita and Patel, Nitisha (2005), FDI in Retail Sector in India, Academic Foundation, ICRIER, New Delhi.

4. Roy, Sujit Kumar, Pandit, Sandip Kumar and Dey, Priya (2012), FDI in MultiBrand Retailing: What Are They Fighting About in India? The Management Accountant, Vol. 47, No. 6, June, p.655

5. Karak, Dilip Kumar and Khamrui, Basanta (2012) FDI in Multi-brand Retail Trade: A Holistic Approach for Indian Economy The Management Accountant, Vol.47, No.6, June, p.659

6. Bhattacharyya, Rajib (2012), The Opportunities and Challenge of FDI in Retail in India, IOSR Journal of Humanities and Social Science, Vol.5, No.5, November-December, p. 103

7. www.dipp.nic.in

8. Ibid

9. www.ibef.org

10. www.dipp.nic.in

11. Ibid 